\title{
Religion as a Health Promoter During the $2019 / 2020$ COVID Outbreak: View from Detroit
}

\author{
Stephen M. Modell ${ }^{1}$ D . Sharon L. R. Kardia ${ }^{1}$ \\ Published online: 16 June 2020 \\ (c) Springer Science+Business Media, LLC, part of Springer Nature 2020
}

\begin{abstract}
The 2019/2020 COVID outbreak has surfaced as a global pandemic. The news has carried stories of the heroic efforts of medical and other health practitioners, with public health officials charting the course of spread. In an urban center like Detroit, the generosity of everyday citizens and church organizations has also played an important role. This inspection of the pandemic from the view of Detroit will examine the epidemiology of the coronavirus, translation of professional practice into people's awareness of the chronic disease risk factors which are prevalent in Detroit, moral and ethical views on the distribution of resources, and three major ways that religious faith has helped to sustain people's health and welfare in the midst of the broad social challenges posed by this novel coronavirus.
\end{abstract}

Keywords COVID-19 - Diabetes · Pandemics · Religion · Ethics · Public health · Urban population $\cdot$ Social environment

\section{Introduction: A Vacated Detroit}

The view from the towering buildings of Detroit captures the brand new Little Caesars hockey-concert arena, budding software companies in adjacent buildings, and the restoration of the 18-story Michigan Central Station shuttered in 1988. But now it displays empty office buildings and roads, like Detroit's central Woodward Avenue, nearly void of cars and pedestrians, all due to COVID-19. As of April 23, 2020, Michigan is seventh in the USA for COVID-19 coronavirus cases $(33,929)$ and third in terms of deaths (2812) (Statista 2020a, b). Most everyone in Detroit and its surrounding communities has been affected. For the authors, the cancelation of

Stephen M. Modell

mod@umich.edu

Sharon L. R. Kardia

skardia@umich.edu

1 Department of Epidemiology, University of Michigan School of Public Health, M5049, SPH II 1415 Washington Hts., Ann Arbor, MI 48109-2029, USA 
a career day presentation at Detroit Country Day School on a typical day in the life of a public health academician turned into a consoling letter for at-home students on the importance of prevention and the essential value of public health among the other health-related professions. A nephew returning in a rush to Chicago from Israel caught the coronavirus and then thankfully recovered within 2 weeks, possibly due to his age, having recently graduated from college. The Centers for Disease Control and Prevention (CDC) released its 13-page Interim Guidance for Administrators and Leaders of Community- and Faith-Based Organizations to Plan, Prepare, and Respond to Coronavirus Disease 2019 (COVID-19) which contained diplomatically worded, now understated instructions to "monitor and plan for absenteeism" (CDC 2020, p. 5). In truth, Detroit is known for its myriad overly active churches, mosques, and synagogues, all of which were ironically desolate on days commemorating the rebirth of a religious figurehead, new meaning and prophetic promise, and the freeing of a people from bondage.

In this inspection of the COVID-19 pandemic, the health status of the city of Detroit will be assessed, considering chronic disease contributors and awareness of those contributors. Resources are in short supply; the ethics of provider and interventional availability will be considered. Community Health Needs Assessments, which in Detroit receive input through the efforts of religious community-based organizations, offer one measure of local health and health policies. Religious faiths have been sustaining the health and well-being of city residents in connection with the pandemic along three broad fronts that will be tied together in the latter portions of this view from Detroit.

\section{Epidemiology Hits Home}

At our institution 45 min from Detroit, as of April 23 the University of Michigan Medical Center reports 175 COVID-19 inpatients, 167 of whom have tested positive (Michigan Medicine 2020). In the heart of Detroit, Henry Ford Hospital reports 185 inpatients testing positive and 3043 outpatients with positive disease status (Henry Ford Health System 2020). About half the cases in Michigan are nested in Wayne County, of which Detroit is the largest city. The CDC and World Health Organization place at higher risk adults over 60 and those with chronic medical conditions (hypertension, obesity, diabetes, lung disease, heart disease, and those with compromised immune systems) (Garg et al. 2020, p. 462). The CDC Office of Public Health Genomics has noted the potential for specific biological factors (the ultimate goal of diagnostic and therapeutic targeting)-ACE2 genetic variants, interleukin-6, HLA antigens, and particular blood groups - to be risk factors in COVID-19 severity and outcome (Khoury et al. 2020). Risk factors for viral transmission and severity should include elucidation of both viral and human genomes and their interaction. However, it also notes the important role environmental, social and economic factors, and compiled "big data" play in this kind of outbreak. Dr. Teena Chopra, an infectious disease professor at Wayne State University who is working with coronavirus patients at Detroit Medical Center, underscores this point: "The high rates of social disadvantage and higher comorbidities make the city of Detroit more vulnerable to 
COVID-19. So these are the reasons why Detroit is, as far as predictions are concerned, showing the steeper curve, and steeper than even New York" (Guardian 2020). About a third of the people in Detroit live in poverty. States Dr. Abdul ElSayed, who resurrected the Detroit Health Department from the city's municipal bankruptcy in 2013, "I think if you're working an \$11-an-hour job that has no paid sick leave and no protection guarantee, that being forced to go out and do your job or lose it in the middle of a pandemic is going to increase your probability of either contracting an infectious disease or transmitting it" (Bach 2020).

Among the COVID-19 biological risk factors, El-Sayed observes that 4 out of 10 Detroit adults are obese, which increases their chances for heart disease and diabetes, and the rate of asthma hospitalizations is more than three times the state average (Nather 2016). Vital statistics supplied by the Michigan Department of Health and Human Services (MDHHS) shed further light on the risk factors within Wayne County. Between 2014 and 2018, Wayne County posted an average of 10,783 hospital discharges and 5366 deaths per year for heart disease; 6035 discharges and 1385 deaths per year for diabetes; 2896 discharges and 28 deaths per year for asthma; and 1456 discharges and 955 deaths per year for lung cancer (MDHHS 2018). Detroit is 79\% African-American, 8.3\% Latino, and 8.5\% white (Henry Ford Health System 2019). Detroit residents suffer chronic disease rates double that of surrounding communities. It can be expected that racial-ethnic minorities represent a disproportionate share of disease cases for the above conditions and COVID-19 in Detroit. In the state of Michigan, which is 14\% African-American, as of April 22, 33\% of COVID cases and $40 \%$ of the deaths are in African-Americans (Mauger and MacDonald 2020).

\section{Translation of Provider Practice to Young Students}

The Detroit Health Department is quite active in the midst of the pandemic, providing free COVID-19 testing; charting the virus' spread in the city by zip code; maintaining a readily viewable COVID-19 Data Dashboard (e.g., showing drive thru testing results and total number of Detroit shelters that are screening); and maintaining a COVID-19 Call Center. These are ambitious activities considering that when El-Sayed took over, the Department was down to 5 people (now it has more than 50). Dr. El-Sayed's efforts are not singular, though. The M.D., M.P.H. down the hallway from the authors is a busy member of the Governor's Michigan Coronavirus Task Force on Racial Disparities. Immediately across from the authors is a flu investigational research group that has been pulling in and compiling influenza, respiratory syncytial virus, and COVID-19 case data from three hospital systems, including Henry Ford Hospital in Detroit, on a daily basis. Heroics take place both in the emergency room and the public health setting.

Shortly after the 2003 severe acute respiratory syndrome (coronavirus SARS$\mathrm{CoV}$ ) pandemic, a Toronto physician who had three previous generation family members die in the Spanish Flu pandemic of 1918 wrote about the ethical clashes a healthcare provider experiences under such circumstances (Sawa 2007, pp. 303-306). Two major dilemmas, and decision points, occur. The provider must 
choose: (1) between the good of an individual person (say, him- or herself or a dear patient) and the well-being of the public and (2) between helping those closest to him or her (family members) and public duty. Sawa concluded, "The solution is not simply to move from a conscience-based ethics to a utilitarian-based approach. There will be conflicts in such circumstances between the public health providers and individuals. At times there may be no obvious or 'correct' answers to the dilemmas which emerge. ... During such crises, moral development is challenged to grow" (Sawa 2007, p. 304). A pragmatic approach would be to streamline the health system. Administrators could anticipate ahead of time the scarcity of resources (vaccines, drugs, ventilators, and hospital beds); assess people's values on their distribution; and train health care workers to make decisions about what would be required of them in the future. Consideration of a pandemic from a moral perspective would challenge providers to consider how they would face different kinds of moral reasoning: Level 5 is that of justice without mercy (i.e., strict utilitarianism); Level 2 "is the level of love based on respect. This level is based not on our love, but on how God loves us." Level 1 transcends this level to one of self-sacrificing love. It requires a flexible balancing between the individual, and the society or community. Ultimate guidance during a pandemic is neither deterministic nor egoistic. It embraces the needs of all parties the provider could help.

The precepts of our current healthcare providers and public health practitioners are guides for future health professionals. For the last 5 years, Michigan State University and the University of Michigan School of Public Health have been hosting the New Genomic Framework for Schools and Communities curriculum in the underserved cities of Detroit and Flint, Michigan. This National Institutes of Healthfunded program has brought an understanding, through classroom experiences and community action projects, of diabetes (sixth grade) and addiction (seventh and eighth grades) to middle school students, their families, and the surrounding community (Bayer et al. 2018). An addiction curriculum panel and mini-workshops composed of adults judging the student projects-representatives from the county health department, health insurance plans, a health research center, and universities-gave students a look at professions that could one day be theirs. The closing event questionnaires and adult interviews also demonstrated an educational type of health preparedness. A teacher attending a diabetes closing event said that he learned about healthy foods and how to prevent diabetes from the students and the professional speaker. Parents interviewed shared how the youngsters learned about diabetes in their father and grandmother, and came home talking about what they eat. A number of students explored the different types of chronic disease which happen to be risk factors in the current dilemma. Detroit closing event participant \#19, a parent, revealed, "She likes to look up different stuff to her question of the day. One example — she looked up stuff about breast cancer, diabetes, and asthma on the Internet." A third level of awareness demonstrated by student and attending community member comments involved connection with broader issues, such as associations with conditions like obesity, and the availability of healthy foods in the inner city. The Science Education Partnership Award (SEPA) program is one way of educating students and their families about chronic disease risk factors, and how they tie in with broader social conditions. 


\section{Social Goods, Community Health Needs Assessments, and Religious Community-Based Organizations}

Detroit and most other American cities are currently experiencing a shortage of resources-testing kits, respirators, and beds-the very items Dr. Sawa's article anticipated. In a city in which one-third of the residents are poor, it would be expedient to provide care to only those who can afford it. Scripture has a perspective on resource bottlenecks. Father Stanley Harakas relates the Eastern Orthodox view: "Neither the ability to pay nor an aristocratic criterion of greater human value or worth is acceptable. ... In spite of the enormous difficulties involved, the ethical imperative from the Orthodox perspective calls for the widest distribution of health care and life-protecting resources facilities and resources, rather than a concentration of such resources for the select few" (Harakas 1980, pp. 26-27). Laurie Zoloth, ethicist and Jewish Studies scholar, refers to Isaiah 68:2 that the poor person is to be valued far above the king: "This is the fast I desire: ... It is to share your bread with the hungry, and to take the wretched poor into your home. When you see the naked, to clothe him and not to ignore your own kin" (Zoloth 1999, p. 245). The 2019 revision of the Public Health Code of Ethics views health justice and equity as core values: "Human flourishing requires the resources and social conditions necessary to secure equal opportunities for the realization of health and other capabilities by individuals and communities. ... In addition, health justice does not pertain only to the distribution of scarce resources in transactions among individuals; it also involves remediation of structural and institutional forms of domination that arise from inequalities related to voice, power, and wealth" (APHA 2019, p. 5).

The attempt in 1994 to establish universal health care by the Clinton administration considered health insurance to be a social good, everybody's right. This view can be contrasted with that of the current Freedom Caucus in the USA, which is that government should not be in the business of providing health insurance, and that it is to be considered a market good (Mack 2019). The 2010 Patient Protection and Affordable Care Act (ACA) has acted under the first premise, despite having been moved closer to the middle since its inception. Among its accomplishments, the ACA has provided health insurance to 20 million Americans who would not otherwise own it. As part of this figure, 14.7 million individuals have been enrolled into Medicaid and the Child Health Insurance Program as a result of Medicaid expansion granting eligibility to people with incomes up to $138 \%$ of the poverty level. Large numbers of people with or at risk of COVID-19 are now entering hospitals through emergency room doors. Hospitals are required to pay for care for those unable to afford it, while the patient remains in emergency, but not to provide follow-up care, such as for surgery or chronic conditions like cancer and diabetes (Mack 2019), risk factors that underlie coronavirus susceptibility. The societal decision in favor of health care as a social good remains vitally important during the outbreak.

The ACA has additionally mandated new IRS requirements for both public and private hospitals to perform a system-wide check-up called a "Community Health 
Needs Assessment" every 3 years, and to adopt an implementation plan addressing community needs. These CHNAs have come to the aid of high racial-ethnic composition, low-income populations in cities like the Bronx of New York, South Chicago, and Detroit. The top three stakeholder identified social determinants of health needs in the 2019 Detroit Henry Ford Health System CHNA were: poverty/low income (\#1 social issue); housing (\#2); and access to healthy food (\#3) (Henry Ford Health System 2019, p. 43). The Michigan Behavioral Risk Factor Survey 2014-2016 shows that 33\% of Detroit residents are overweight and 37\% are obese, health characteristics the CHNA reports to be on the rise. In addition, the Henry Ford Macomb Hospital, located north of Detroit, reported diabetes as a priority area.

Implementation goals in these locations-increased consumption of fruits and vegetables and reduction of body mass index (BMI) in diabetic patients - bear more than a passing resemblance to the dietary and exercise-related lessons in our middle school genomics curriculum, leading us to believe we have given shape to at least a few students' future ambitions. We appreciate that other states will have different priorities. South of the Michigan border in Franklin County, Ohio, which contains that state's metropolitan capitol, Columbus, chronic conditions are \#5 on the list of prioritized health needs, and infectious diseases (vaccine-preventable infections, sexually-transmitted diseases) are \#6 (Mount Carmel Health System 2019, p. v). The health priorities in both states' health systems are relevant to the theme of coronavirus prevention.

In the 2019 Henry Ford Health System CHNA, input was gathered by a variety of mechanisms, including stakeholder surveys, focus groups, and community member feedback. The types of organizations providing input to the CHNA were health-related, educational, civic, and faith-based, among other categories. In Detroit, 5 of the 11 organizations providing input were faith-based (e.g., Second Baptist Church of Detroit, Lord of Lords Church, and Faith Community Nursing). Our research team has long been aware of the importance of religious community-based organizations for recruiting grass-roots participants for values discussions and dialogs relating to new health interventions. In our NIH-funded Communities of Color and Genetics Policy project looking at people's attitudes toward new genetic technologies, 5 of the 14 participating community organizations were faith-based (e.g., Bethel AME Church in Ann Arbor, MI; Faith Access to Community Economic Development in Flint, MI; and Clinica Santa Maria in Grand Rapids, MI) (Bonham et al. 2009, p. 336). Members of these churches and organizations were entirely African-American and Latino, affording a distinct look at the hopes and concerns of people who have experienced marginalization, discrimination, and transience in their own lives. Detroit has many active communitybased organizations. The churches and other faith-based organizations are especially aware of the social obstacles and healthcare deficits experienced by their community members. 


\section{The Religious Factor in Health Promotion and the Current Crisis}

Religious involvement in health promotion represents both sides of the coin. On the heads side, religion serves as a source of hope, which is greatly needed emotionally and in a life-sustaining sense during the current crisis. On the other side, religion provides practical services that bolster health and welfare. Many people consider themselves more spiritual than religious, but it is the organized nature of religious institutions that is coming to the rescue during the widespread financial and food shortages being experienced. In public health, we consider health promotion to be mediated by health facilitators and deterred by health barriers, which are often physical factors or people advocating for health (Kieffer et al. 2005, p. 149). In the current dilemma, religion as a health promoter is active in terms of what the churches, temples, and mosques are accomplishing, and their members are carrying out.

\section{Church-Based Health Programs}

It is important to recognize that churches have been longstanding partners in health promotion along with public health and medical organizations. Lasater and colleagues divide health-related church activity into four levels: (I) The church serving only as a venue for recruiting participants into collaborative health programs; (II) the intervention delivery occurs on-site at the church, e.g., educational sessions and group classes; (III) involvement of congregation members in program delivery, as might be carried out by trained lay health workers from within congregational ranks; and (IV) delivery of program elements that include both health messages and religious readings, such as scriptural or ethical guidance, that link religion and health (Campbell et al. 2007, p. 217; Lasater et al. 1997, pp. S49-S50). A level II diabetes prevention program implemented in 15 Bronx and Harlem churches in New York was aimed at improving nutrition and physical activity levels utilizing a consultant fluent in Spanish from the community with a faith orientation, and another who was a nutrition and diabetes educator (Gutierrez et al. 2014). A Level III prevention program aimed at obesity, diabetes, and hypertension in 8 African-American Mississippi Delta churches contained dietary/physical activity educational sessions led by program staff and a trained church committee member (Tussing-Humphreys et al. 2013). A level IV diabetes prevention program in 20 African-American churches in Augusta, Georgia, was based on 12 core information and risk improvement sessions and utilized input from a community (faith-based) and university advisory board in all aspects of project planning. The board's recommendations resulted in the inclusion of select scriptures and sociocultural preferences in the Group Lifestyle Balance curriculum (Sattin et al. 2016).

These programs registered statistically significant outcomes in regards excess eating, blood glucose levels, physical activity level, and personal weight; two involved control arms; and the Bronx-Harlem program stratified results by race-ethnicity, including identification of group-specific obstacles and motivating factors. Churchbased programs are not contoured for late secondary prevention; that is, treating the manifestation of disease like diabetes or cancer. However, they do have a place in 
primary prevention of disease by mitigating the risk factors involved. The effects of these three programs will not end when the programs themselves end. The church participants are left with new knowledge and tools which can be utilized at any time. In fact, most people during the pandemic have found themselves sequestered to home, where time exists to engage in one's preferred physical activity, and to manage the content of meals, at least as far as these practices relate to the first three chronic disease risk factors for COVID-19.

\section{Providing Hope}

Pondering the universe's vastness and our capacity to take a fall while traversing it, Emerson affirmed, "We judge of a man's wisdom by his hope" (Emerson 1951, p. 98). Compared to tangible interventions, hope is a more abstract quality, but one that can lead to health and the will to seek it. Paul Scherz (2018) delineates three stances toward Scripture that pertain to personalized medicine: (1) setting aside anxieties over risk and leaving worldly concerns to God's care; (2) using natural regularities to provide security while realizing that the future is in God's hands; and (3) looking to social factors that structure risk, such as friends or the work environment. These avenues of hope can be generalized to the diversity of religious faiths. While the first stance has been used in decisions over whether to except a newborn from neonatal blood screening, the consequences of leaving population health purely to God and fate during a pandemic are quite stark. Even invoking the goal of herd immunity free of intervention would lead to hundreds of thousands of deaths. Better an appreciation that God, or one's personal definition of a universal presence, abides with us as we experience calamity and take whatever steps seem wise. Indeed, a British study on the knowledge and beliefs of patients newly diagnosed with cancer found that fatalistic beliefs ("cancer is caused by fate and nothing can be done to prevent it") explained only $4.6 \%$ of the variance in anxiety scores over the spread of cancer (Lord et al. 2012, p. 8). Other attitudes toward the spread of disease supersede a sense of fatalism in people's hopes and fears about what might eventuate.

A sense of hope provided by religion can determine whether one engages in healthy practices in the disease context or lets things slide. Two interviews from patients with diabetes, the second recovering from a lower leg amputation, depict this stance:

My happiness would be within Him. ... And when I'm at peace, then my body is at peace. I start doing things, I start going to church or wherever I need to go to worship, exercise, time for this and that (Choi and Hastings 2019, p. 10). [Spirituality] helps to get by, just like every day. It helps with getting out of bed and getting on with the day, and just do something. It helps to try to walk and "I can do it, yes I can do it, I can do it ..." And I can't do it now, but I can do it, I will do it (Unantenne et al. 2013, p. 1153).

These statements also apply to conditions in the middle of the COVID pandemic. Healthy people out of work and without the normal activities of daily living need inspiration to keep moving. For people grieving a loved one or personally recovering 
from the virus, a sense of hope can help them to simply get through the day. A third patient refers to the hope spirituality can give through people on whom one can rely:

It does help me because you realize you've got support ... you've got other people of a like mind around you, and it gives you the strength to keep going ... a vision that goes alongside your everyday living. You draw strength from it for everyday living ... (Unantenne et al. 2013, p. 1152).

In the inner city, other people can be very helpful in times of crisis. Detroit has stories of teachers going to homes and asking what residents need, immigrant specialists delivering diapers and food to their clients, and neighbors tilling the soil of nearby community gardens for each other as summer approaches (Alvarez and Clark 2020). Churches that allowed ten congregants per service early in the outbreak, which provided emotional support to helpers and those being helped alike, have stopped this practice in the wake of state disease prevention rules promulgated by Gov. Gretchen Whitmer. Places of worship have been determined and resourceful, though, adapting to circumstances by holding drive-in (in-vehicle) and online services, and transmitting messages of hope on the social media. In Detroit, places of worship have been responsive and adaptive to policy. Perhaps, the biggest transmitted message of hope was delivered by renowned Italian opera singer Andrea Bocelli on Easter Sunday 2020 when he conducted a one man performance entitled "Music for Hope" in the foreground of Milan's Duomo Cathedral with the goal of uniting the world during the pandemic. The mission was a success, breaking live-stream classical music records with an all-time 35 million views.

\section{Providing Social Services}

The most evident symbol of religious involvement in sustaining the health of Detroit citizens during the pandemic lies in the essential social services the churches are performing. Residents are reeling from inability to go to work and the closure of food establishments. The city is already known for being a "food desert" marked by a shortage of nearby grocery stores and healthy food markets. Here is an example listing of the services churches are rendering during the outbreak:

- Drive-through food pantries (All Saints Soup Kitchen and Food Pantry, Emmanuel Lutheran Church, St. Christine's Christian Services)

- Carry-out soup kitchens (St. Christine's Christian Services, St. Leo's Soup Kitchen, Capuchin Soup Kitchen, Pope Francis Center)

- Free grocery delivery to unemployed workers, single mothers, senior citizens, and the physically disabled (Triumph Church)

- Lunch delivery to health care workers (New Family Church, Wings of Love Ministries)

- Student laptop loans (Triumph Church)

These services are most frequently performed on behalf of those who for a variety of reasons have been marginalized from what most families take for granted, 
though with the outbreak, this circle has enlarged. The persons and organizations delivering these services are the unsung heroes of COVID-19. We are especially appreciative of the laptop provision to young students (Allen 2020), having tested with our middle school students the use of Chromebooks and iPads to visualize how genes interact with the environment in Sand Rat simulations and to model the effects of gene-environment interactions on health using a dynamic model building program, and found that computers seem to be a favored learning method among middle school students! Schools are closed during the pandemic, but not all families have computers to upload online lessons. Triumph's generous efforts will help both young students and their families.

The educational project is a collaboration; the schools themselves provided the digital device and computer laboratory access. Neighbors preparing community gardens for each other; deliveries by one community resident to another; social services being performed by the churches; churches securing laptops for young students during school closure-these attributes are known as "community assets" (Wallerstein et al. 2005, p. 34). In the midst of calamity, Detroit is both depending on an expert healthcare system and bringing its own community assets to bear.

\section{Conclusion: Collaboration out of Chaos}

Charles Dickens opens his classic novel A Tale of Two Cities with the well-known statement: "It was the best of times, it was the worst of times ... it was the season of Light, it was the season of Darkness, it was the spring of hope, it was the winter of despair..." (Dickens 1997, p. 13). Though this passage was directed at the contrast between British and French society and the haves and have nots, it very much applies to current circumstances, especially to urban centers swirling in the eye of the pandemic. Divisions exist between the different sectors and those who have enough to get by living alongside families barely surviving.

The city's functioning displays the socio-ecological model in operation, not just as a chalkboard conception (Modell et al. 2013, p. 114; Campbell et al. 2007, pp. 215-216). The overall incidence of infection depends on its incidence among population subgroups, which is contingent on its diagnosis at the site of testing. Access to medical care is linked with steps that are being taken in the work environment and home environment. The survival of critical cells helps assure functioning at the organ level (heart, lungs, and immune system), which governs an individuals' health, with influence from their surrounding family, community, and the country's level of preparedness. The two vectors in the model- "the world affects us" and "we affect the world"-represent the necessary collaboration taking place, a bit different from the social clashes of Dicken's novel.

The newspapers of mid-April provide a slice in history of a city roiling in pandemic yet arched toward recovery if the fates will permit it. One can trace different strands in the city's reaction. The pandemic has affected each individual to the core, exposing deeply human emotions. People working together, and unfortunately the spread of disease between people, show it to be a social phenomenon, with churches as salutary, ever working participants. For scientists and medical and public health practitioners, it 
is a time of great, amassed energy, trying to contain the spread and keep people alive. In the April 27/May 4, 2020, "Finding Hope" special issue of Time Magazine, the Dalai Lama captured this point in history with the following words:

This crisis shows that we must all take responsibility where we can. We must combine the courage doctors and nurses are showing with empirical science to begin to turn this situation around and protect our future from more such threats. ... As a Buddhist, I believe in the principle of impermanence. Eventually, this virus will pass, as I have seen wars and other terrible threats pass in my lifetime, and we will have the opportunity to rebuild our global community as we have done many times before (Dalai Lama 2020, p. 54).

In Dickens' Great Expectations, the protagonist Philip Pirrip ("Pip") is the beneficiary of an unexpected fortune, but at the same time he experiences hardships from the continued aloofness of Estelle, the imprisonment and death of his benefactor, Magwitch, and the consequent loss of his (Pip's) fortune to the Crown and by helping his friend financially (Dickens 1996, pp. 299, 458, 461). Toward the very end Pip has regained his footing through sheer work and self-initiative to become a senior partner in his friend's firm, and in Dickens' revision the hint exists that the cruelties of life have made Estelle into an enduring companion. Before the crisis, the view from the tall buildings of Detroit was of a city on the rise. The COVID-19 pandemic has gutted the health and well-being of the major American cities, with Detroit at the front. On the road to recovery, which is matter of time, patience, and collective effort, Detroit's residents and those in the surrounding communities will surely depend on the types of faith the Dalai Lama has articulated.

Acknowledgements The authors extend their gratitude to Irene Bayer for reviewing the SEPA projectrelated portions of the manuscript.

Author's Contribution SM was the principal writer of the manuscript and provided the majority of references. SK was responsible for the educational and Community Health Needs Assessment material in the manuscript, in addition to helping with the structuring of the paper and providing a thorough review of the manuscript.

\section{Compliance with Ethical Standards}

Conflict of interest The authors declare that they have no conflict of interest.

Ethics Approval This piece complies with applicable national and institutional ethical guidelines. Statements in this article from the authors' research are part of a study determined by the University of Michigan Health Sciences and Behavioral Sciences Institutional Review Board to comprise exempt human subjects research.

\section{References}

Allen, M. (2020). Detroit church adapts to pandemic with drive-in services, loaner laptops for students. Retrieved April 23, 2020, from https://thegrio.com/2020/04/11/detroit-church-adapts-to-pandemicwith-drive-in-services-loaner-laptops-for-students. 
Alvarez, S., \& Clark, A. (2020). In battle-tested Detroit, neighbors help each other as coronavirus spreads. Retrieved April 23, 2020, from https://www.bridgemi.com/urban-affairs/battle-teste d-detroit-neighbors-help-each-other-coronavirus-spreads.

American Public Health Association. (2019). Public health code of ethics. Washington, DC: American Public Health Association.

Bach, T. (2020). Why COVID-19 is a disaster for Detroit. U. S. News \& World Report. Retrieved April 23, 2020, from https://www.usnews.com/news/cities/articles/2020-04-08/why-coronaviru s-is-a-disaster-for-detroit.

Bayer, I., Greene-Moton, E., Modell, S. M., Adler, I., Tal, T., \& Citrin, T. (2018). Impact and lessons learned from a school-academic-community partnership in sharing urban youth community research projects on type-2 diabetes as a health promotion strategy. In 146th American Public Health Association annual meeting and exposition, Philadelphia, PA, November 14, 2018. Retrieved April 23, 2020, from https://apha.confex.com/apha/2018/meetingapp.cgi/Paper/41629 4.

Bonham, V. L., Citrin, T., Modell, S. M., Franklin, T. H., Bleicher, E. W. B., \& Fleck, L. M. (2009). Community-based dialogue: Engaging communities of color in the United States' genetics policy conversation. Journal of Health Politics, Policy and Law, 34(3), 325-359.

Campbell, M. K., Hudson, M. A., Resnicow, K., Blakeney, N., Paxton, A., \& Baskin, M. (2007). Church-based health promotion interventions: Evidence and lessons learned. Annual Review of Public Health, 28, 213-234.

Centers for Disease Control and Prevention. (2020). Interim guidance for administrators and leaders of community- and faith-based organizations to plan, prepare, and respond to coronavirus disease 2019 (COVID-19). Retrieved April 23, 2020, from https://www.cdc.gov/coronavirus/2019ncov/community/organizations/guidance-community-faith-organizations.html.

Choi, S. A., \& Hastings, J. F. (2019). Religion, spirituality, coping, and resilience among African Americans with diabetes. Journal of Religion \& Spirituality in Social Work, 38(1), 93-114.

Dickens, C. (1996). Great expectations. New York: Penguin Classics.

Dickens, C. (1997). A tale of two cities. New York: Signet Classic.

Emerson, R. W. (1951). Spiritual laws. Emerson's essays, 1st and 2nd series (pp. 93-120). New York: Harper Colophon Books.

Garg, S., Kim, L., Whitaker, M., O’Halloran, A., Cummings, C., Holstein, R., et al. (2020). Hospitalization rates and characteristics of patients hospitalized with laboratory-confirmed coronavirus disease 2019-COVID-NET, 14 States, March 1-30, 2020. Morbidity and Mortality Weekly Report, 69(15), 458-464.

Guardian. (2020). Detroit: America's next COVID-19 hotspot battles to prepare for coming surge. Retrieved April 23, 2020, from https://www.theguardian.com/us-news/2020/mar/31/detroitcoronavirus-america-michigan-poverty.

Gutierrez, J., Devia, C., Weiss, L., Chantarat, T., Ruddock, C., Linnell, J., et al. (2014). Evaluation of a multicultural faith-based diabetes prevention program. Diabetes Educator, 40(2), 214-222.

Harakas, S. S. (1980). For the health of body and soul: An Eastern Orthodox introduction to bioethics. Brookline, MA: Holy Cross Orthodox Press.

Henry Ford Health System. (2019). Community health needs assessment 2019. Retrieved April 23, 2020, from https://www.henryford.com/-/media/files/henry-ford/about/community/chna-2019-final-henryfordcom.pdf?la=en.

Henry Ford Health System. (2020). Henry Ford Health System COVID-19 cases. Retrieved April 23, 2020, from https://www.henryford.com/services/infectious-diseases/conditions/covid-19-coron avirus.

Khoury, M. J., Gwinn, M., \& Duggal, P. (2020). The public health impact of COVID-19: Why host genomics? Retrieved April 23, 2020, from https://blogs.cdc.gov/genomics/2020/04/21/the-publi c-health-impact.

Kieffer, E. C., Salabarria-Pena, Y., Odoms-Young, A. M., Willis, S. K., Baber, K. E., \& Guzman, J. R. (2005). The application of focus group methodologies to community-based participatory research. In B. A. Israel, E. Eng, A. J. Schulz, \& E. A. Parker (Eds.), Methods in communitybased participatory research for health (pp. 146-166). San Francisco: Jossey-Bass.

Lama, D. (2020). Thoughts, not prayers. Time, 195(15-16), 54-55.

Lasater, T. M., Becker, D. M., Hill, M. N., \& Gans, K. M. (1997). Synthesis of findings and issues from religious-based cardiovascular disease prevention trials. Annals of Epidemiology, 7(S7), s46-s53. 
Lord, K., Mitchell, A. J., Ibrahim, K., Kumar, S., Rudd, N., \& Symonds, P. (2012). The beliefs and knowledge of patients newly diagnosed with cancer in a UK ethnically diverse population. Clinical Oncology, 24(1), 4-12.

Mack, J. (2019). What America needs to decide: Is health care a market good or social good? Retrieved April 30, 2020, from https://www.mlive.com/opinion/kalamazoo/2012/07/what_america_needs_to_ decide_i.html.

Mauger, C., \& MacDonald, C. (2020). Michigan's COVID-19 cases, deaths hit blacks disproportionately. Detroit News. Retrieved April 23, 2020, from https://www.detroitnews.com/story/news/local/michi gan/2020/04/02/michigans-covid-19-deaths-hit-417-cases-exceed-10-700/5113221002.

Michigan Department of Health and Human Services. (2018). Vital statistics-Selected chronic disease indicators, Wayne County Health Department residents 2016-2018. Retrieved April 23, 2020, from http://www.mdch.state.mi.us/pha/osr/chi/profiles/frame.asp.

Michigan Medicine. (2020). COVID-19 update. Retrieved April 23, 2020, from https://mmheadline s.org/2020/april-22-daily-covid-19-update.

Modell, S. M., Kardia, S. L. R., Citrin, T., \& King, S. B. (2013). The ecological model in genetics and religion. In G. Simpson \& S. Payne (Eds.), Religion and ethics (pp. 99-121). Hauppauge, NY: Nova Science Publishers.

Mount Carmel Health System. (2019). 2019 Community health needs assessment. Retrieved April 23, 2020, from https://www.mountcarmelhealth.com/assets/documents/mcgc-chna-2019.pdf.

Nather, D. (2016). In the poorest big city in America, he's bringing the health department back to life. Retrieved April 23, 2020, from https://www.statnews.com/2016/05/03/detroit-health-director.

Sattin, R. W., Williams, L. B., Dias, J., Garvin, J. T., Marion, L., Joshua, T. V., et al. (2016). Community trial of a faith-based lifestyle intervention to prevent diabetes among African-Americans. Journal of Community Health, 41(1), 87-96.

Sawa, R. J. (2007). Bioethics for the twenty-first century. Ultimate Reality and Meaning: Interdisciplinary Studies in the Philosophy of Understanding, 30(4), 301-313.

Scherz, P. (2018). Risk in Christianity and personalized medicine: Three frameworks for understanding risk in Scripture. In 7th Annual conference on medicine \& religion, St. Louis, Missouri, April 13-15, 2018. Retrieved February 25, 2018, from www.medicineandreligion.com/risk-in-christianity.html.

Statista. (2020a). Total number of cases of coronavirus (COVID-19) in the United States as of April 23, 2020, by state. Retrieved April 23, 2020, from https:/www.statista.com/statistics/1102807/coron avirus-covid19-cases-number-us-americans-by-state.

Statista. (2020b). Number of deaths from coronavirus (COVID-19) in the United States as of April 23, 2020, by state. Retrieved April 23, 2020, from https:/www.statista.com/statistics/1103688/coron avirus-covid19-deaths-us-by-state.

Tussing-Humphreys, L., Thomson, J. L., Mayo, T., \& Edmond, E. (2013). A church-based diet and physical activity intervention for rural, lower Mississippi Delta African American adults: Delta body and soul effectiveness study, 2010-2011. Preventing Chronic Disease, 10, E92.

Unantenne, N., Warren, N., Canaway, R., \& Manderson, L. (2013). The strength to cope: Spirituality and faith in chronic disease. Journal of Religion and Health, 52(4), 1147-1161.

Wallerstein, N., Duran, B., Minkler, M., \& Foley, K. (2005). Developing and maintaining partnerships with communities. In B. A. Israel, E. Eng, A. J. Schulz, \& E. A. Parker (Eds.), Methods in community-based participatory research for health (pp. 31-51). San Francisco: Jossey-Bass.

Zoloth, L. (1999). Health care and the ethics of encounter: A Jewish discussion of social justice. Chapel Hill, NC: University of North Carolina Press.

Publisher's Note Springer Nature remains neutral with regard to jurisdictional claims in published maps and institutional affiliations. 